\title{
Incidence of Soybean vein necrosis virus in Alabama Soybean Fields
}

Edward J. Sikora, ${ }^{\dagger}$ Kassie N. Conner, and Alana L. Jacobson, Department of Entomology and Plant Pathology, Alabama Cooperative Extension System, Auburn University, AL, 36849-5624

Accepted for publication 5 February 2018.

\section{Abstract}

Soybean vein necrosis virus (SVNV) was first reported in the United States during 2008 and has since rapidly spread to all major soybean-producing regions of North America. In 2013, a 4-year study was initiated to determine the distribution and incidence of the virus in Alabama soybean fields and potential weed hosts in the state. The weed host survey focused on populations of morning glory growing adjacent to maturing soybeans fields, along with additional commonly occurring weed species found in Alabama. SVNV was detected throughout Alabama ( 27 of 28 counties tested) and was most common in the northern region of the state. The average incidence of SVNV in fields in northern Alabama increased from $31.8 \%$ in 2013 to $82.6 \%$ in 2016 . Average incidence of the virus in central Alabama soybean fields ranged from 5.1 to $14.8 \%$, and southern Alabama fields ranged from 0 to $8.8 \%$ over the 3 -year period. Only one population of morning glory tested positive for SVNV during the 3-year survey of this potential weed host. None of the 15 additional weed species screened tested positive for SVNV. This study has demonstrated that SVNV is found in Alabama soybean fields throughout the state and that soybeans grown in northern Alabama are at greater risk for infection.
Soybean vein necrosis (SVN), caused by Soybean vein necrosis virus (SVNV), was first detected on soybeans (Glycine max [L.] Merrill) in the United States in Arkansas and Tennessee during 2008 (Tzanetakis et al. 2009). The disease has since been reported throughout the soybean-growing regions of the United States, as well as Ontario, Canada (Ali and Abdalla 2013; Conner et al. 2013; Han et al. 2013; Jacobs and Chilvers 2013; Khatabi et al. 2012; Smith et al. 2013a; Tenuta 2012; Zhou et al. 2011; Zhou and Tzanetakis 2013). Soybean plants expressing symptoms typical of SVN were first observed in northern Alabama in Limestone County in October 2012 (Conner et al. 2013). Symptoms consisted of brown necrotic tissue along the major veins of the upper and lower leaf surface, resulting in a scorched appearance of infected leaves (Fig. 1). Symptomatic plants were observed in six additional soybean fields in Limestone County during the 2012 growing season.

SVNV is the only known Tospovirus to infect soybeans in the United States, with the exception of Tomato spotted wilt virus, which was detected in Alabama in 2008 (Sikora et al. 2011). SVNV is a distinct species of the genus Tospovirus within the family Bunyaviridae (Khatabi et al. 2012; Zhou et al. 2011). SVNV is primarily transmitted by soybean thrips, Neohydatothrips variabilis (Beach) (Zhou and Tzanetakis 2013). Tobacco thrips, Frankliniella fusca (Hinds), and Eastern flower thrips, Frankliniella tritici (Fitch), can also transmit SVNV, but at a lower efficiency than soybean thrips (Keough et al. 2016). In a study conducted in 2015 , Jacobson et al. (2016) found that $65 \%$ of the thrips species collected in Alabama soybean fields were soybean thrips, $17 \%$ were Eastern flower thrips, $17 \%$ were poinsettia thrips (Echinothrips americanus [Morgan]), and less than $1 \%$ were tobacco thrips, with soybean thrips found throughout the growing season.

${ }^{\dagger}$ Corresponding author: Edward J. Sikora; E-mail: sikorej@auburn.edu

Funding: This work was funded by the Alabama Soybean Producers

(C) 2018 The American Phytopathological Society

\section{Additional Hosts Associated with SVNV}

Zhou and Tzanetakis (2013) detected SVNV in ivyleaf morning glory (Ipomoea hederacea Jacq) growing in a SVNV-infested soybean field in Arkansas. Ivyleaf morning glory is an indigenous species in soybean fields, and its natural distribution appears to overlap with the occurrence of SVNV and soybean thrips in the midSouth region (Sweeden and McLeod 1993; USDA 2012b). Ivyleaf morning glory was one of nine Ipomoea spp. found in Alabama (Patterson et al. 1998). Entireleaf morning glory, I. hederacea var. integriuscula (Gray), and pitted morning glory, I. lacunose (L.), are both more commonly observed growing near commercial soybean fields throughout the state. Other known hosts of SVNV that have been shown to sustain SVNV replication include Dendranthema grandiflorum, Cucurbita pepo, Vigna unguiculata, V. radiata, Nicotiana benthamiana, N. tabacum, and N. glutinosa (Zhou and Tzanetakis 2013).

SVNV is considered the most widespread virus of soybean in the United States and is found in more than $98 \%$ of fields surveyed (Zhou et al. 2011). The objectives of this study were to determine the distribution of SVNV in Alabama, measure incidence of the virus within individual fields in the state, and identify weed hosts of SVNV near soybean fields. To determine the distribution and incidence of SVNV in Alabama, a survey was conducted in 99 soybean fields from 2013 to 2016 . Weed host studies focused on populations of entireleaf and pitted morning glory growing adjacent to maturing soybeans fields, along with 15 additional weed species.

\section{Soybean Survey: Methodology}

Commercial soybean fields and soybean fields located on Alabama Agricultural Experiment Stations were surveyed for SVNV from 2013 to 2016. Individual field locations varied from year to year because of crop rotation practices followed by growers in the state. When possible, individual fields were sampled in multiple years. The majority of fields targeted for this study were in North Alabama counties, where the bulk of the soybean acreage is planted (Price 2016). The survey was expanded in 2014 to include an increased number of fields in central and southern Alabama to gain 
a more complete picture of the distribution of the disease in the state.

Ninety-nine fields were sampled over the 4-year period. Fifteen fields were sampled in 2013, 29 fields in 2014, 30 fields in 2015, and 25 fields in 2016. Leaf samples were collected at reproductive growth stage R5 (pod fill) or R6 (full pod) (Fehr et al. 1971). To maintain consistency, leaf samples were collected by only one person (lead author) for virus testing. The majority of fields surveyed were planted with group V soybean cultivars, although cultivars varied by location, year, grower preference, and seed availability.

Fifty trifoliate leaves (one per plant) were collected from each field in the survey. A trifoliate sample was removed from the upper canopy of five contiguous plants at 10 locations within a 1-acre field section. A priority was placed on collecting leaves that showed symptoms typical of SVN. Leaves were stored in plastic bags in a cooler and were transported to the laboratory for processing within 24 to $36 \mathrm{~h}$ after collection. A leaflet of each trifoliate sample expressing SVN symptoms was tested individually for SVNV with polyclonal antibodies using a double-antibody sandwich enzyme-linked immunosorbent assay (ELISA) (Agdia, Elkhart, IN) according to the manufacturer's instructions. If symptoms of SVN were not visible, then the central leaflet of the trifoliate sample was tested for the virus. Absorbance values were read with a microplate reader and considered positive for SVNV when the absorbance value $(405 \mathrm{~nm})$ was greater than the average ELISA absorbance value plus three standard deviations of three healthy soybean leaf samples added to each microtiter plate. Incidence was determined based on the number of plants testing positive for SVNV out of the 50 plants screened per field.

\section{Weed Survey: Methodology}

A survey of morning glory growing adjacent to soybean fields was conducted in 2014 to 2016. Samples were collected at the same time that soybean leaf samples were collected from the adjacent field, and both sets of samples were tested for the presence of SVNV. Entireleaf morning glory comprised six of the seven populations sampled in 2014 , seven of the nine populations in 2015, and one of two populations collected from a single field in 2016. Pitted morning glory made up the remaining populations sampled. A 15-in. section of vine with multiple leaves attached from the top of the plant was removed from approximately 20 plants for each population screened. Because symptoms of SVN were not visible on the morning glory samples, 2 to 3 leaves weighing approximately $2 \mathrm{~g}$ when combined were tested for the presence of the virus. Morning glory samples were tested using ELISA procedures previously outlined for soybean.

In 2015, various weed species were collected from the border area of a field in Limestone County, where soybeans were heavily infected with SVNV (100\% incidence) the previous year. Plant samples were collected from an area approximately $300 \mathrm{ft}$ long and within $20 \mathrm{ft}$ of the field edge. The field was planted to wheat in the fall of 2014 and was eventually planted to corn for the 2015 growing season. Approximately 20 whole-plant specimens of each weed species were collected on March 18, May 11, and November 4, 2015. Samples were tested using ELISA procedures previously outlined for soybean.

\section{SVNV Distribution in Alabama}

SVNV was detected in 27 of 28 counties tested during this 4-year study (Fig. 2). The disease was found in seven new counties in 2013, including Etowah, Fayette, Jackson, Lauderdale, Lawrence, Madison, and Morgan (Table 1). All seven counties were located in northern Alabama, where the survey was focused that year. SVNV was found in all 12 northern Alabama fields surveyed in 2013, with incidence ranging from 8 to $58 \%$ (average $31.8 \%$ ). SVNV was not detected in the Macon County field in central Alabama nor in the two southern Alabama fields surveyed during 2013.

SVNV was found in 14 new counties in 2014, with many of these counties located in central and southern Alabama (Table 1). SVNV was
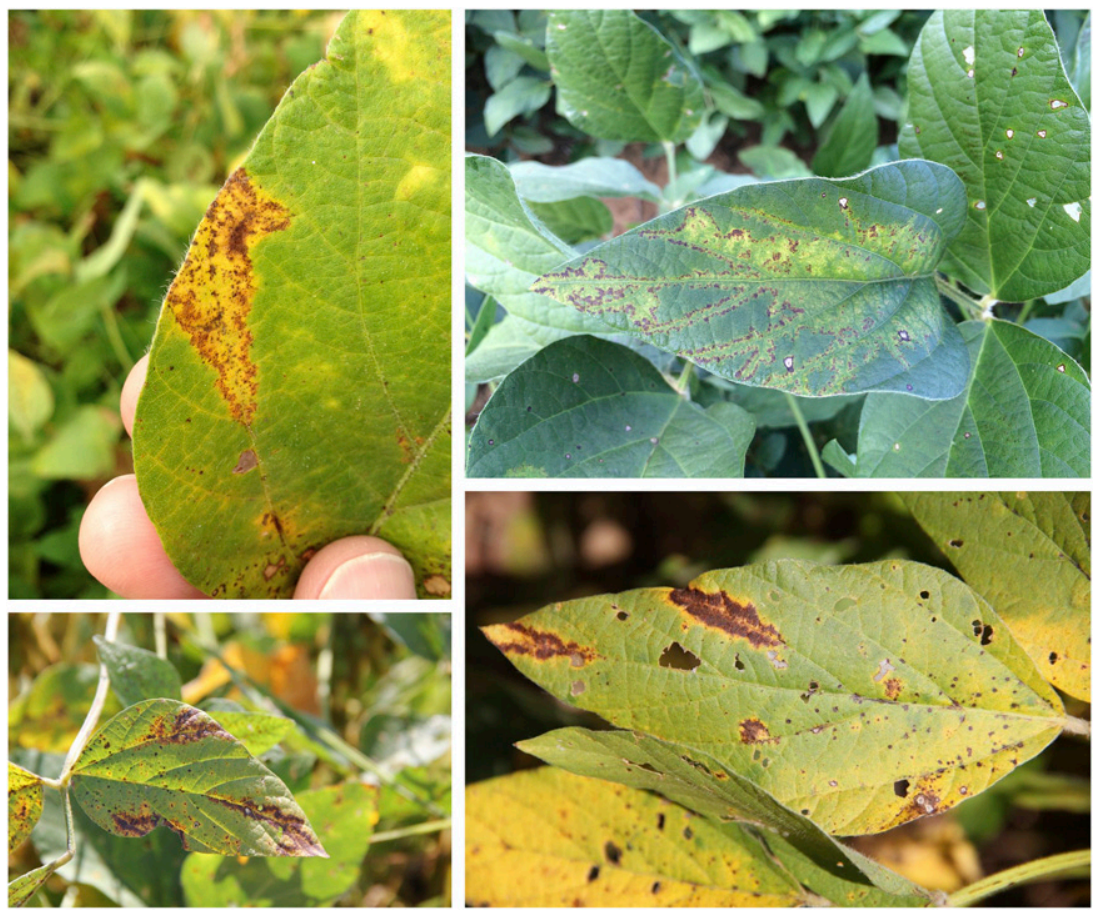

FIGURE 1

Symptoms of Soybean vein necrosis virus consist of brown necrotic tissue along major veins. 
detected in all 11 fields surveyed in northern Alabama, with incidence ranging from 22 to $100 \%$ (average $61.0 \%$ ). Fields in Limestone and Madison counties reached an incidence of $100 \%$. SVNV was detected in six new counties in central Alabama, including Elmore, Greene, Pickens, Russell, Talladega, and Tuscaloosa. SVNV was found in all eight central Alabama fields surveyed, with incidence ranging from 4 to $20 \%$ (average $11.8 \%$ ). SVNV was also found in four new counties in southern Alabama, including Baldwin, Covington, Escambia, and Washington. SVNV was found in eight of the nine fields surveyed in this region, with incidence ranging from 0 to 22\% (average 8.8\%).

SVNV was found in six new counties in 2015, including Blount and DeKalb counties in northern Alabama and Dallas, Lee, Macon, and Perry counties in central Alabama (Table 1). SVNV was detected in all 16 fields surveyed in northern Alabama, with incidence ranging from 22 to $90 \%$ (average 64.0\%). SVNV was detected in five of seven fields surveyed in central Alabama, with incidence ranging from 0 to $70 \%$ (average 14.8\%). SVNV was also found in five of the seven fields surveyed in south Alabama, with incidence ranging from 0 to $28 \%$ (average $7.7 \%$ ).

In 2016, we focused our efforts on fields and counties where the disease was detected previously to compare incidence levels over multiple years. Incidence of the disease within a field was highest in northern Alabama, with two fields reaching $100 \%$. SVNV was detected in all 10 fields surveyed in northern Alabama, with incidence ranging from 48 to $100 \%$ (average $82.6 \%$ ). SVNV was detected in four of seven fields surveyed in central Alabama, where

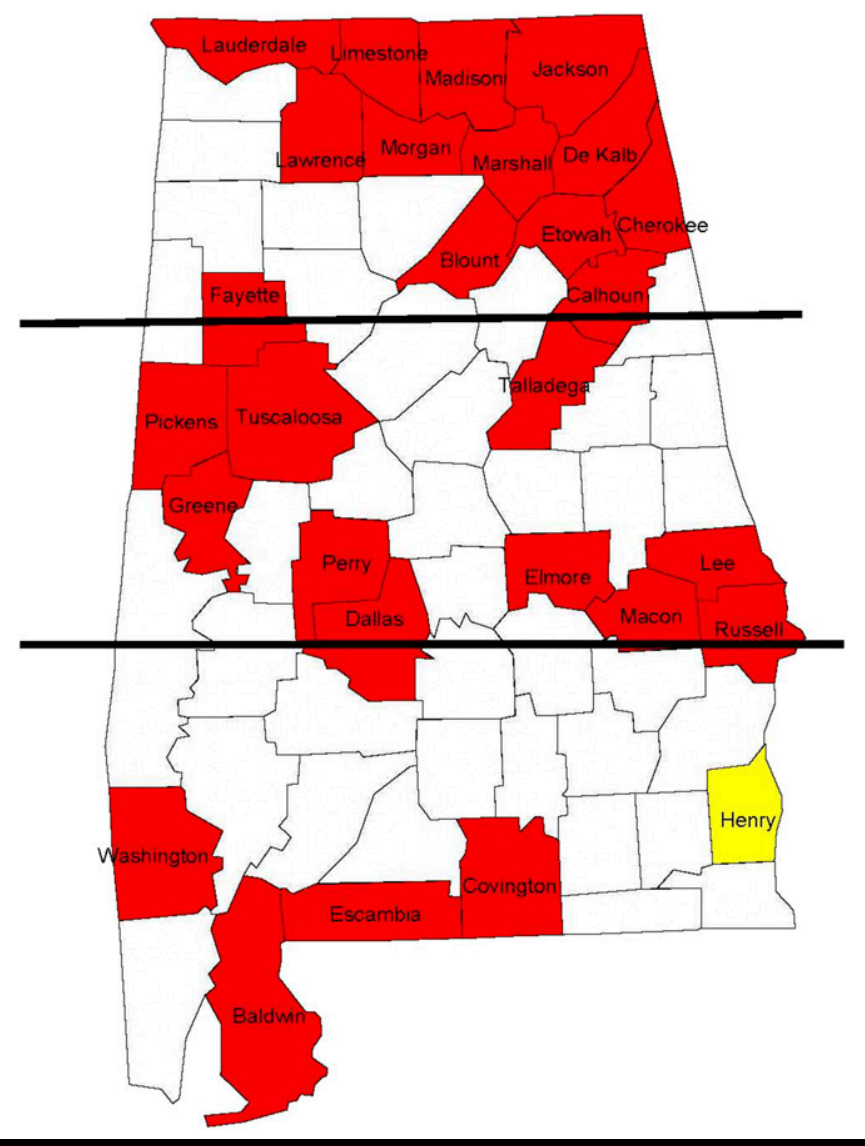

FIGURE 2

Map of Alabama showing the state divided into northern, central, and southern regions; red counties indicate Soybean vein necrosis virus (SVNV) was detected in at least one field in that county during this study; yellow county indicates SVNV was sampled but not detected. incidence ranged from 0 to $18 \%$ (average $5.1 \%$ ). SVNV was not detected in the seven fields surveyed in southern Alabama.

\section{Incidence of SVNV Highest in Northern Alabama}

Every field sampled in northern Alabama during the 4-year study tested positive for SVNV, with incidence ranging from 8 to $100 \%$ (Table 1). The average incidence of SVNV in fields in this region increased from $31.8 \%$ in 2013 , to $61 \%$ in 2014 , to $64 \%$ in 2015 , to a high of $82.6 \%$ in 2016, and a minimum of 10 fields were surveyed each year (Table 1). Average incidence of SVNV in central Alabama fields ranged from 5.1 to $14.8 \%$ from 2014 to 2016 . Average incidence of SVNV in southern Alabama fields ranged from 0 to $8.8 \%$ over the same 3-year period.

Fourteen fields in northern Alabama were surveyed for SVNV in multiple years during this study. Incidence of SVNV typically increased in subsequent years (Table 1). In some cases, the difference in incidence in the ensuing year was dramatic (DeKalb-2, Lauderdale-1, Lauderdale-2, Lawrence-1, Limestone-2, Limestone-5, Madison-2, and Marshall-1). SVNV incidence decreased in four fields in subsequent years (Limestone-2, Madison-2, Madison-3, and Marshall2 ), although incidence in years prior to the modest drop-off in these fields was relatively high, ranging from 62 to $100 \%$.

Fields in central and south Alabama, where SVNV incidence reached above $28 \%$ in only one field, did not display the trends observed in northern Alabama, with a few exceptions. SVNV incidence for Elmore-1 went from $12 \%$ in 2014 , to $70 \%$ in 2015, to $0 \%$ in 2016. SVNV incidence for Escambia-2, which was sampled in all four years of the study, peaked in 2014 at $22 \%$; however, incidence in 2013 (0\%), 2015 (2\%), and $2016(0 \%)$ was minimal. SVNV was never detected in Henry County in the southeast corner of Alabama, with at least one field surveyed each year from 2014 to 2016.

\section{Weed Survey}

Only one population of morning glory in 2014 tested positive for SVNV during the 3-year survey of this weed (Table 2). The virus was detected in four of the 20 entireleaf morning glory plants collected from this population. The morning glory was growing next to a soybean field in Madison County in northern Alabama that had $100 \%$ incidence of SVN that year (Table 1). Incidence of SVNV ranged from 4 to $50 \%$ in the six other soybean fields adjacent to where morning glory tested negative for the pathogen in 2014 . The virus was not detected in the morning glory populations collected during 2015 or 2016. Incidence of SVNV in the adjacent soybean fields ranged from 0 to $82 \%$ for the nine morning glory populations surveyed in 2015. Incidence of SVNV was $96 \%$ in the adjacent soybean field for the populations of entireleaf and pitted morning glory tested in 2016. SVNV was not detected in the 15 weed species collected over the three sampling dates in 2015 (Table 3).

\section{Summary}

SVNV was detected in 27 counties in Alabama during this study, including those in which at least 5,000 acres of soybeans are planted annually (Price 2016). Because Alabama covers roughly 336 miles from north to south, we grouped counties into three regions (north, central, and south). Nine of the top 10 soybean-producing counties reside in the northern Alabama tier (Price 2016).

Although SVNV was detected in all three regions of the state, it was clear the disease was most common in northern Alabama (Table 1). Variation in thrips and noncrop plant host species could vary among climactic and ecological zones, with the state divided into three major geographically defined hardiness zones running north to 


\begin{tabular}{|c|c|c|c|c|}
\hline \multicolumn{5}{|c|}{$\begin{array}{c}\text { TABLE } 1 \\
\text { Percent incidence of Soybean vein necrosis virus (SVNV) in } \\
\text { Alabama soybean fields in } 2013 \text { (15 fields), } \\
2014 \text { ( } 29 \text { fields), } 2015 \text { ( } 30 \text { fields), and } 2016 \text { ( } 25 \text { fields) }\end{array}$} \\
\hline County and field & $2013^{a}$ & 2014 & 2015 & 2016 \\
\hline \multicolumn{5}{|l|}{ Northern Alabama } \\
\hline Blount & & & 70 & \\
\hline Calhoun-1 & & 50 & & \\
\hline Calhoun-2 & & & & 56 \\
\hline Cherokee-1 & & 22 & & \\
\hline Cherokee-2 & & 30 & & \\
\hline DeKalb-1 & & 62 & & \\
\hline DeKalb-2 & & & 46 & 100 \\
\hline DeKalb-3 & & & 90 & \\
\hline Etowah-1 & 10 & & & \\
\hline Etowah-2 & & & 66 & \\
\hline Fayette & 20 & & & \\
\hline Jackson-1 & 56 & & & \\
\hline Jackson-2 & 38 & & & \\
\hline Jackson-3 & & & & 68 \\
\hline Lauderdale-1 & 32 & & 82 & \\
\hline Lauderdale-2 & 10 & & 72 & \\
\hline Lawrence-1 & 8 & 94 & & \\
\hline Lawrence-2 & 16 & & 26 & \\
\hline Lawrence-3 & & 88 & & \\
\hline Limestone-1 & 54 & & 52 & \\
\hline Limestone-2 & 54 & 100 & 80 & 96 \\
\hline Limestone-3 & & 50 & & \\
\hline Limestone 4 & & & 84 & 90 \\
\hline Limestone-5 & & & 54 & 92 \\
\hline Madison-1 & 26 & & & \\
\hline Madison-2 & & 24 & 88 & 80 \\
\hline Madison-3 & & 100 & & 96 \\
\hline Madison-4 & & & 22 & \\
\hline Marshall-1 & & 52 & 84 & 100 \\
\hline Marshall-2 & & & 62 & 48 \\
\hline Morgan-1 & 58 & & & \\
\hline Morgan-2 & & & 46 & \\
\hline Total fields, average & $12,31.8 \%$ & $11,61.0 \%$ & $16,64.0 \%$ & $10,82.6 \%$ \\
\hline \multicolumn{5}{|l|}{ Central Alabama } \\
\hline Dallas-1 & & & 6 & \\
\hline Dallas-2 & & & & 14 \\
\hline Elmore-1 & & 12 & 70 & 0 \\
\hline Elmore-2 & & & 0 & \\
\hline Green-1 & & 4 & 0 & \\
\hline Greene-2 & & 4 & & \\
\hline Lee-1 & & & 4 & \\
\hline Lee-2 & & & & 0 \\
\hline Macon-1 & 0 & & 14 & 2 \\
\hline Perry & & & 10 & \\
\hline Pickens-1 & & 16 & & \\
\hline Pickens-2 & & 6 & & \\
\hline Pickens-3 & & & & 2 \\
\hline Russell & & 20 & & \\
\hline Talladega-1 & & 18 & & \\
\hline Talladega-2 & & & & 18 \\
\hline Tuscaloosa-1 & & 14 & & \\
\hline Tuscaloosa-2 & & & & 0 \\
\hline Total fields, average & $1,0 \%$ & $8,11.8 \%$ & $7,14.8 \%$ & $\begin{array}{r}7,5.1 \% \\
\text { (Continued) }\end{array}$ \\
\hline
\end{tabular}

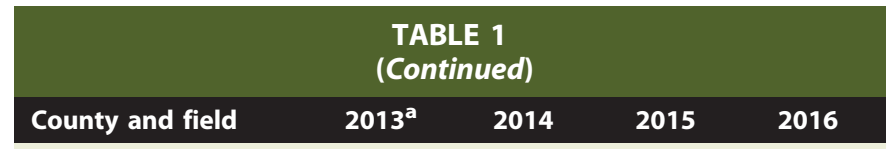

Southern Alabama

\begin{tabular}{|c|c|c|c|c|}
\hline Baldwin-1 & & 6 & & \\
\hline Baldwin-2 & & 16 & & \\
\hline Baldwin-3 & 0 & 8 & 12 & \\
\hline Baldwin-4 & & 4 & & \\
\hline Baldwin-5 & & & 28 & \\
\hline Baldwin-6 & & & 6 & 0 \\
\hline Baldwin-7 & & & & 0 \\
\hline Covington & & 12 & & \\
\hline Escambia-1 & & 4 & & \\
\hline Escambia-2 & 0 & 22 & 2 & 0 \\
\hline Escambia-3 & & & & 0 \\
\hline Henry-1 & & 0 & 0 & 0 \\
\hline Henry-2 & & & 0 & \\
\hline Henry-3 & & & & 0 \\
\hline Henry-4 & & & & 0 \\
\hline Washington-1 & & 4 & & \\
\hline Washington-2 & & & 6 & \\
\hline Total fields/average & $2,0 \%$ & $9,8.8 \%$ & $7,7.7 \%$ & $7,0 \%$ \\
\hline
\end{tabular}

${ }^{\mathrm{a}}$ Incidence based on number of plants testing positive for SVNV out of 50 plants tested per field.

\begin{tabular}{|c|c|c|c|c|}
\hline \multicolumn{5}{|c|}{$\begin{array}{l}\text { TABLE } 2 \\
\text { Incidence of Soybean vein necrosis virus (SVNV) in entireleaf } \\
\text { or pitted morning glory in Alabama soybean fields surveyed } \\
\text { from } 2014 \text { to } 2016\end{array}$} \\
\hline $\begin{array}{l}\text { County } \\
\text { and field }\end{array}$ & $\begin{array}{l}\text { Entireleaf } \\
\text { morning } \\
\text { glory }^{\mathrm{a}}\end{array}$ & $\begin{array}{l}\text { Pitted } \\
\text { morning } \\
\text { glory }\end{array}$ & $\begin{array}{l}\text { Incidence in } \\
\text { soybean } \\
\text { field }(\%)^{b}\end{array}$ & Year \\
\hline Calhoun-1 & $0 / 20$ & & 50 & 2014 \\
\hline Escambia-1 & $0 / 20$ & & 4 & 2014 \\
\hline Madison-2 & $0 / 20$ & & 24 & 2014 \\
\hline Madison-3 & $4 / 20$ & & 100 & 2014 \\
\hline Pickens-1 & $0 / 15$ & $0 / 10$ & 16 & 2014 \\
\hline Talladega-1 & $0 / 20$ & & 18 & 2014 \\
\hline Tuscaloosa-1 & $0 / 20$ & & 14 & 2014 \\
\hline Baldwin-5 & $0 / 20$ & & 14 & 2015 \\
\hline DeKalb-2 & $0 / 20$ & & 46 & 2015 \\
\hline Etowah-2 & $0 / 20$ & & 66 & 2015 \\
\hline Henry-1 & $0 / 20$ & & 0 & 2015 \\
\hline Limestone-1 & $0 / 20$ & & 52 & 2015 \\
\hline Limestone-4 & $0 / 20$ & & 84 & 2015 \\
\hline Lauderdale-1 & & $0 / 20$ & 82 & 2015 \\
\hline Lauderdale-2 & & $0 / 20$ & 72 & 2015 \\
\hline Macon-1 & $0 / 20$ & & 14 & 2015 \\
\hline Madison-3 & $0 / 24$ & $0 / 20$ & 96 & 2016 \\
\hline
\end{tabular}

${ }^{a}$ Number of entireleaf or pitted morning glory samples testing positive for SVNV over total samples tested.

${ }^{b}$ Percent incidence of soybean plants testing positive for SVNV out of 50 plants tested in field adjacent to morning glory population screened.

south (USDA 2012a) and containing five ecological zones where soybean production occurs (EPA 2000). Differences in incidence across the state could be owing to differences in thrips-vector-species composition; fewer soybean thrips are observed in southern Alabama soybean fields compared with northern Alabama (Jacobson, personal 


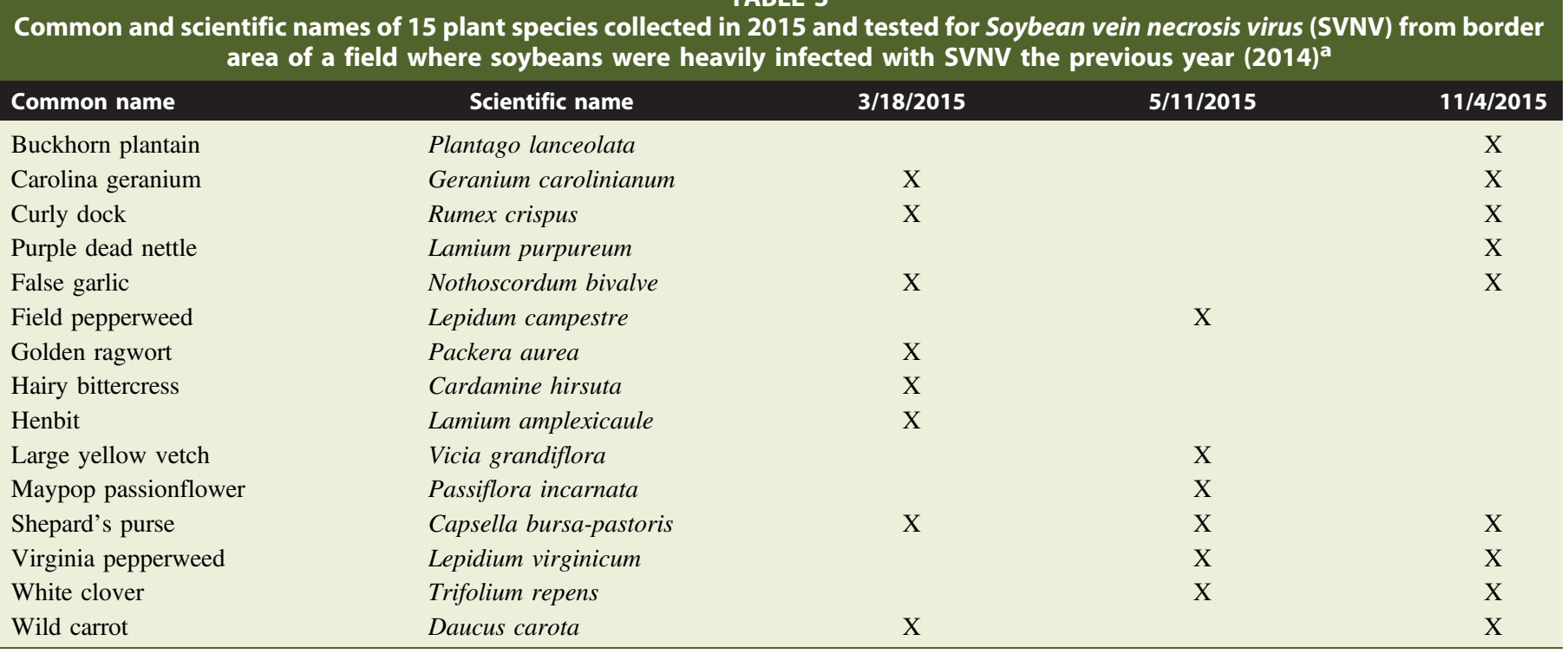

${ }^{a} \mathrm{X}$ indicates weed species that were collected on that date and tested for SVNV. Ten specimens of each species were tested on each sampling date.

communication). It is also possible that one or more plant species that are more common in northern Alabama act as overwintering hosts for SVNV. The fact that the majority of soybean acres are located in northern Alabama may also favor increases in SVNV in the landscape over time because of the abundance of crop hosts that may also support populations of thrips vectors. More information about distribution of host plants and thrips vectors is needed to better understand differences in SVNV observed in this study.

The average incidence of SVNV in fields in northern Alabama increased incrementally from $31.8 \%$ in 2013 to $82.6 \%$ in 2016 (Table 1). The increase in SVNV incidence during this period may indicate inoculum levels have increased each year since the disease was first reported in Alabama in 2012 (Conner et al. 2013). Average temperatures for the state during the growing season (June to September) increased each year of the survey from $77.6^{\circ} \mathrm{F}(2013)$, to $78.8^{\circ} \mathrm{F}(2014)$, to $79.4^{\circ} \mathrm{F}$ (2015), to $82.0^{\circ} \mathrm{F}$ (2016). Precipitation during this 4-month period was 7.2 in. above normal in 2013, $5.4 \mathrm{in.}$ below normal in 2014, and near normal in 2015 and 2016 (U.S. Climate Data 2017). Although it is possible the annual increase in temperatures or precipitation events may have influenced populations of thrips vectors, plant hosts, or virus-host interactions in Alabama during this period, more information is needed to draw conclusions about the influence of abiotic factors on SVN epidemiology and increases in incidence over time.

The lack of an incremental increase in SVNV incidence over time in soybean fields in central and southern Alabama suggests the disease may not reach the incidence levels observed in northern Alabama. This would likely be the result of a combination of low populations of efficient vectors, relatively low soybean acreage, and/or the absence of a suitable overwintering host for the virus in these regions. We will continue to monitor SVNV in all regions of the state to determine if there is a shift in SVN incidence over time.

Only one population of morning glory tested positive for SVNV during the 3-year survey of this potential weed host (Table 2). This population of entireleaf morning glory was growing adjacent to a soybean field that had $100 \%$ incidence of SVNV, indicating that virus inoculum levels were high at this location. It was reported that SVNV was detected in ivyleaf morning glory growing in a SVNVinfested soybean field in Arkansas (Zhou and Tzanetakis 2013). We tested numerous populations of morning glory growing near soybean fields where incidence of SVNV ranged from 0 to $96 \%$, but the inability to detect the virus in at least one additional population may indicate entireleaf and pitted morning glory are not reliable hosts for this virus (Table 2). SVNV was not detected in the 15 additional weed species collected over the three sampling dates in 2015 (Table 3). We suspect there are additional hosts besides soybean in Alabama that would allow SVNV to overwinter in the state. ELISA was used for detection of SVNV in this study. However, it has been shown that polymerase chain reaction (PCR) protocols are consistently more reliable than ELISA for virus detection purposes (Groves et al. 2016; Smith et al. 2013b; Zhou and Tzanetakis 2013). It is probable that utilizing a PCR protocol would have increased the number of positive detections of SVNV in soybean, as well as improved the likelihood of detecting SVNV in asymptomatic weeds.

This study has demonstrated that SVNV can be found in Alabama soybean fields throughout much of the state and that soybeans grown in northern Alabama are at greater risk for infection. Although SVNV has become widespread in the state, the potential impacts on yield are unknown. However, results from a multistate study that included Alabama indicated that SVN influenced the quality and chemical composition of harvested soybean seed (Anderson et al. 2017).

\section{Literature Cited}

Ali, A., and Abdalla, O. A. 2013. First report of Soybean vein necrosis virus in soybean fields of Oklahoma. Plant Dis. 97:1664.

Anderson, N. R., Irizarry, M. D., Bloomingdale, C. A., Smith, D. L., Bradley, C. A., Delaney, D. P., Kleczewski, N. M., Sikora, E. J., Mueller, D. S., and Wise, K. A. 2017. Effect of soybean vein necrosis on yield and seed quality of soybean. Can. J. Plant Pathol. 39:334-341.

Conner, K., Sikora, E. J., Zhang, L., and Burmester, C. 2013. First report of Soybean vein necrosis-associated virus affecting soybeans in Alabama. Online publication. Plant Health Prog. doi.org/10.1094/PHP-2013-0729-03-BR

EPA. 2000. Ecoregions of Alabama and Georgia. http://ecologicalregions.info/ data/ga/alga_front.pdf

Fehr, W. R., Caviness, C. E., Burmood, D. T., and Pennington, J. S. 1971. Stage of development descriptions for soybeans, Glycine max (L.) Merrill. Crop Sci. 11:929-931.

Groves, C., German, T., Dasgupta, R., Mueller, D., and Smith, D. L. 2016. Seed transmission of soybean vein necrosis virus: The first Tospovirus implicated in seed transmission. PLoS One 11:e0147342.

Han, J., Domier, L. L., Dorrance, A. E., and Qu, F. 2013. First report of Soybean vein necrosis-associated virus in Ohio soybean fields. Plant Dis. 97:693. 
Jacobs, J. L., and Chilvers, M. I. 2013. First report of Soybean vein necrosis virus on soybeans in Michigan. Plant Dis. 97:1387.

Jacobson, A., Sikora, E., and Conner, K. 2016. Monitoring thrips vectors of Soybean vein necrosis virus in Alabama. Pages 41-42 in: Auburn University Crops: Soybean Research Report 2015, No. 46. K. S. Lawrence, D. Delaney, and D. Monks, eds. Alabama Agricultural Experiment Station, Auburn, AL.

Keough, S., Han, J., Shuman, T., Wise, K., and Nachappa, P. 2016. Effects of Soybean vein necrosis virus on life history and host preference of its vector, Neohydatothrips variabilis, and evaluation of vector status of Frankliniella tritici and F. fusca. J. Econ. Entomol. 109:1979-1987.

Khatabi, B., Wen, R.-H., Hershman, D. E., Kennedy, B. S., Newman, M. A., and Hajimorad, M. R. 2012. Generation of polyclonal antibodies and serological analyses of nucleocapsid protein of Soybean vein necrosis-associated virus: A distinct soybean infecting Tospovirus serotype. Eur. J. Plant Pathol. 133: 783-790.

Patterson, M., Monks, D., Boozer, B., and Bannon, J. 1998. Weed identification for horticultural crops. ANR-1128. Alabama Cooperative Extension System, Auburn. http://www.aces.edu/pubs/docs/A/ANR-1128/ANR-1128.pdf.

Price, C. 2016. Alabama county estimates: Soybeans 2014-2015. USDA-NASS, Washington, D.C. https://www.nass.usda.gov/.

Sikora, E. J., Murphy, J. F., Lawrence, K. S., and Mullen, J. M. 2011. Survey of fungal, nematode and virus diseases of soybean in Alabama. Online publication. Plant Health Prog. doi.org/10.1094/PHP-2011-1227-01-RS

Smith, D. L., Fritz, C., Watson, Q., Willis, D. K., German, T. L., Phibbs, A., Mueller, D., Dittman, J. D., Saalau-Rojas, E., and Whitham, S. A. 2013a. First report of soybean vein necrosis disease caused by Soybean vein necrosisassociated virus in Wisconsin and Iowa. Plant Dis. 97:693.

Smith, D. L., Groves, C. L., Fritz, C., and Willis, D. K. 2013b. Development and validation of quantitative polymerase chain reaction protocols for detection of Soybean vein necrosis virus. Phytopathology 103:S2.135.

Sweeden, M. B., and McLeod, P. J. 1993. Seasonal occurrence of thrips (Thysanoptera) on cowpeas in western Arkansas and northeast Oklahoma. J. Entomol. Sci. 28:427-432.

Tenuta, A. 2012. First confirmation of soybean vein necrosis in Ontario. Online publication. OMAFRA Field Crop News. http://fieldcropnews.com/2012/09/ first-confirmation-of-soybean-vein-necrosis-virus-in-ontario/.

Tzanetakis, I., Wen, R., Newman, M., and Hajimorad, R. 2009. Soybean vein necrosis virus: A new threat to soybean production in Southeastern United States? Phytopathology 99:S131.

U.S. Climate Data. 2017. U.S. climate data for Alabama. https://www.usclimatedata. com/climate/alabama/united-states/3170.

USDA. 2012a. Plant hardiness zone map. Agricultural Research Service, U.S. Department of Agriculture. http://planthardiness.ars.usda.gov.

USDA. 2012b. Plant profile: Ipomoea herderacea Jacq. Ivyleaf morning-glory. https://plants.usda.gov/java/profile?symbol=iphe

Zhou, J., Kantartzi, S. K., Wen, R. H., Newman, M., Hajimorad, M. R., Rupe, J. C., and Tzanetakis, I. E. 2011. Molecular characterization of a new tospovirus infecting soybean. Virus Genes 43:289-295.

Zhou, J., and Tzanetakis, I. E. 2013. Epidemiology of Soybean vein necrosisassociated virus. Phytopathology 103:966-971. 